Pasquaud, S. etal. Determination of fish trophic levels in an estuarine system Estuarine Coastal and Shelf Science, $n^{\circ}$ 86. p. 237-246. 2010

http://www.sciencedirect.com/science?_ob=PublicationURL\&_tockey=\%23TOC\%236776\%232010\%23999139997\%231578281\%23FLA\%23\&_cdi=

\title{
1 Determination of fish trophic levels in an estuarine system
}

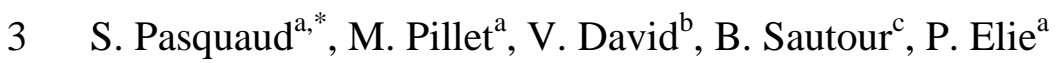

$4{ }^{a}$ Cemagref, groupement de Bordeaux, Estuarine Ecosystems and Diadromous Fish Research

5 Unit, 50 avenue de Verdun, 33612 Cestas Cedex, France

$6 \quad$ stephanie.pasquaud@ cemagref.fr

$7 \quad$ pillet.marion@gmail.com

8 pierre.elie@cemagref.fr

9 b UMR LIENSs 6250 CNRS/Université de La Rochelle, Institut du Littoral et de

10 l'Environnement, 2 rue Olympes de Gouges, 17000 La Rochelle, France

11 valerie.david@univ-lr.fr

$12{ }^{\mathrm{c}}$ UMR 5805 EPOC - OASU, Université de Bordeaux 1, 2 Rue du Professeur Jolyet, 33120

13 Arcachon, France

14 b.sautour@epoc.u-bordeaux1.fr

* Corresponding author. Tel. +33557890980-Fax. +33557890801 
Pasquaud, S. etal. Determination of fish trophic levels in an estuarine system

Estuarine Coastal and Shelf Science, $n^{\circ}$ 86. p. 237-246. 2010

http://www.sciencedirect.com/science?_ob=PublicationURL\&_tockey=\%23TOC\%236776\%232010\%23999139997\%231578281\%23FLA\%23\& cdi=

\section{Abstract}

The concept of trophic level is particularly relevant in order to improve knowledge of the structure and the functioning of an ecosystem. A precise estimation of fish trophic levels based on nitrogen isotopic signatures in environments as complex and fluctuant as estuaries requires a good description of the pelagic and benthic trophic chains and a knowledge of organic matter sources at the bottom. In this study these points are considered in the case of the Gironde estuary (south west France, Europe). To obtain a good picture of the food web, fish stomach content analyses and a bibliographic synthesis of the prey feeding ecology were carried out. Fish trophic levels were calculated from these results and $\delta^{15} \mathrm{~N}$ data. The feeding link investigation enabled us to identify qualitatively and quantitatively the different preys consumed by each fish group studied, to distinguish the prey feeding on benthos from those feeding on pelagos and to characterize the different nutritive pools at the base of the system. Among the species studied, only Liza ramada and the flatfish (Platichthys flesus and Solea solea) depend mainly on benthic trophic compartments. All the other fish groups depend on several trophic (benthic and/or pelagic) sources. These results enabled us to correct the calculation of fish trophic levels which are coherent with their feeding ecology data obtained from the nitrogen isotopic integrative period. The present work shows that trophic positions are linked with the feeding ecology of fish species and vary according to individual size.

Ecological data also allow the correction of the isotopic data by eliminating absurd results and showing the complementarity of the two methods. This work is the first to consider source variability in the fish food web. This is an indispensable step for trophic studies in a dynamic environment. The investigation of matter fluxes and recycling processes at the food web base would provide an useful improvement in future estuarine food web research. 
Pasquaud, S. etal. Determination of fish trophic levels in an estuarine system Estuarine Coastal and Shelf Science, $n^{\circ}$ 86. p. 237-246. 2010

http://www.sciencedirect.com/science?_ob=PublicationURL\&_tockey=\%23TOC\%236776\%232010\%23999139997\%231578281\%23FLA\%23\&_cdi=

39 Keywords: stomach contents; $\delta^{15} \mathrm{~N}$; predator-prey relationships; organic matter sources; fish

40

trophic levels; estuarine ecosystem

41 Regional index terms: Europe; France; Gironde estuary; Lat. $45^{\circ} 20^{\prime} \mathrm{N}$; Long. $0^{\circ} 45^{\prime} \mathrm{W}$ 
Pasquaud, S. etal. Determination of fish trophic levels in an estuarine system

Estuarine Coastal and Shelf Science, $n^{\circ}$ 86. p. 237-246. 2010

http://www.sciencedirect.com/science?_ob=PublicationURL\&_tockey=\%23TOC\%236776\%232010\%23999139997\%231578281\%23FLA\%23\& cdi=

\section{Introduction}

In recent years, there has been increased interest in use of carbon and nitrogen stable isotopes to characterize the trophic web structure and the energy flows of aquatic ecosystems (e.g. Kwak and Zedler, 1997). For a living being, the carbon isotope ratio ${ }^{13} \mathrm{C} /{ }^{12} \mathrm{C}$ provides an estimate of the origin of the assimilated organic matter (De Niro and Epstein, 1978; Fry and Sherr, 1984; Post, 2002) and the nitrogen carbon ratio ${ }^{15} \mathrm{~N} /{ }^{14} \mathrm{~N}$ gives its trophic level (De Niro and Epstein, 1981; Minagawa and Wada, 1984; Hesslein et al., 1991; Wada et al., 1991). For fish, stable isotope analysis represents a complementary approach to traditional feeding studies: stomach contents reflect the qualitative and quantitative ingestion of species at a given time whereas stable isotope analyses represent an integrative record of the food that has really been assimilated by the fish during a period prior to the sampling (e.g. Persson and Hansoon, 1999; Davenport and Bax, 2002; West et al., 2003; Winemiller et al., 2007). The isotopic integrative time varies from days to years according to the ecosystem, the species, their growth rate and the tissue considered (Tieszen et al., 1983; Hesslein et al., 1993; Guelinckx et al., 2007; Church et al., 2009; Suring and Wing, 2009). For example, Perga \& Gerdeaux (2003) have estimated that the $\delta^{13} \mathrm{C}$ and $\delta^{15} \mathrm{~N}$ of muscle tissue only reflected the food consumed during the spring and summer growth period.

The combined use of these two methods can provide a detailed picture of the structure of an estuarine fish food web by i) describing trophic relationships between different biological compartments (stomach contents analyses) and ii) estimating the trophic position of species one alongside the other (nitrogen stable isotope analyses) (e.g. West et al., 2003; Akin and Winemiller, 2008).

In the Gironde estuary, $\delta^{15} \mathrm{~N}$ seemed to be a good marker to improve knowledge of the food web structure, even if anomalies in fish trophic positions have been identified (Pasquaud 
Pasquaud, S. etal. Determination of fish trophic levels in an estuarine system Estuarine Coastal and Shelf Science, $n^{\circ}$ 86. p. 237-246. 2010

http://www.sciencedirect.com/science?_ob=PublicationURL\&_tockey=\%23TOC\%236776\%232010\%23999139997\%231578281\%23FLA\%23\&_cdi=

et al., 2008). For example, Platichthys flesus, a predator of small benthic crustaceans has a

higher average $\delta^{15} \mathrm{~N}$ level than Argyrosomus regius which tends to be ichtyophagous. These observations can be explained by an enrichment of the $\delta^{15} \mathrm{~N}$ signatures in benthic species compared to pelagic species for an equivalent trophic position (e.g. Sherwood and Rose, 2005). Moreover, a precise estimation of the fish trophic positions requires knowledge of sources at the bottom of the food chains (Vander Zanden et al., 1997; Vander Zanden and Rasmussen, 1999; Sherwood and Rose, 2005; Pasquaud et al., 2008).

The aim of the present study was to characterize fish trophic levels precisely according to their size class from $\delta^{15} \mathrm{~N}$ values, taking account of variability. Hence, the objectives were (1) to determine the food chains during the nitrogen isotopic integrative period in the Gironde estuary from fish stomach content analyses and from literature data for the prey; (2) to attribute to each fish species (or size class) studied a baseline $\delta^{15} \mathrm{~N}$ value taking into account the proportion of benthic/pelagic prey in their feeding and the $\delta^{15} \mathrm{~N}$ signatures of the nutritive pool identified, and (3) use this information to calculate fish/size class trophic levels.

\section{Materials and methods}

\subsection{Study area}

The Gironde estuary is located in South West France $\left(45^{\circ} 20^{\prime} \mathrm{N}, 0^{\circ} 45^{\prime} \mathrm{W}\right.$; Fig. 1). It is $12 \mathrm{~km}$ wide at the mouth and $76 \mathrm{~km}$ long between the ocean and the Bec d'Ambès, where the Garonne and Dordogne rivers meet and which also constitutes the upstream salinity limit. The watershed of this system represents an area of $81000 \mathrm{~km}^{2}$. The hydrodynamic conditions are highly variable due to the interactions of marine and fluvial flows, leading to temperature and salinity gradients. There are also considerable seasonal variations. During the period under 
Pasquaud, S. etal. Determination of fish trophic levels in an estuarine system Estuarine Coastal and Shelf Science, $n^{\circ}$ 86. p. 237-246. 2010

http://www.sciencedirect.com/science?_ob=PublicationURL\&_tockey=\%23TOC\%236776\%232010\%23999139997\%231578281\%23FLA\%23\&_cdi= selected.

114

\subsection{Fish stomach content analyses}

\subsection{Sampling surveys}

consideration (April to September 2004), discharge values varied widely with a flood event in spring (up to 3,600 m.s $\mathrm{s}^{-3}$ in May) and an important drought period in summer (about $250 \mathrm{~m} . \mathrm{s}^{-3}$ from July to September; unpublished data). In consequence, salinity values varied and were especially low in June 2004. Temperatures stayed relatively high in summer, fluctuating between 13.1 and $24.7^{\circ} \mathrm{C}$. The dynamic conditions involved high turbidity values reaching 500 mg.L $\mathrm{L}^{-1}$ (Sottolichio and Castaing, 1999; David et al., 2007) and a restricted light penetration. In consequence, primary production was reduced and the food web seems based on the detritus pool (Lobry et al., 2008). In spite of these constraining conditions, the Gironde estuary shows a high biodiversity and seems to be a particularly well-preserved ecosystem.

Fish were sampled approximately bimonthly from April 2004 to September 2004, across ten stations located in the upstream area of the saline Gironde estuary (Fig. 1). An otter trawl (4 m opening and a cod-end with a mesh size of $8 \mathrm{~mm}$ ) was used. Fish sampling was carried out during daylight hours at high tide and was restricted to 15-minute episodes in order to limit regurgitation or abnormal feeding. All the sampled fish were identified, counted, weighed, measured and finally frozen until laboratory analysis could be carried out. Some of the most abundant fish species or genus, separated in some cases into size classes, are presented here (Table 1). Only cohorts spending the totality of their spring and summer growth period (i.e. period considered in that study, see paragraph 2.3.) inside the system were 
Pasquaud, S. etal. Determination of fish trophic levels in an estuarine system Estuarine Coastal and Shelf Science, $n^{\circ}$ 86. p. 237-246. 2010

http://www.sciencedirect.com/science?_ob=PublicationURL\&_tockey=\%23TOC\%236776\%232010\%23999139997\%231578281\%23FLA\%23\& cdi=

The fish stomach contents were analyzed in order to describe their trophic

relationships during the nitrogen isotopic integrative time in the Gironde estuary (Table 1).

119 Crossing literature information (Tieszen et al., 1983; Perga and Gerdeaux, 2005; Miller, 2006;

120 Guelinckx et al., 2007), we have estimated that the $\delta^{15} \mathrm{~N}$ of the muscle tissue (used in these

121 isotopic analyses, see Pasquaud et al., 2008 for more details) reflected the food consumed

122 during the warm growth period, i.e. from April to September. It is important to note that we

123 only selected specimens belonging to the same cohorts during the period considered, i.e. we

124 took account for the individual growth along the integrative time.

The different items were examined under binocular microscope and identified to the

highest possible taxonomic separation. The volume of each prey was estimated using the

127 point method described by Pillay (1952) and Hyslop (1980). analyzed. Even if these data do not provide this species food variability over the isotopic integrative period, they were nevertheless considered to give data elements on its feeding ecology and thus to estimate the origin of the organic matter at the base of its trophic chain in

132 the Gironde estuary.

134 Almeida et al. (1993) and Laffaille et al. (2002): a $200 \mathrm{mg}$ sample was removed from the stomach and suspended in $5 \mathrm{ml}$ of formaldehyde (5\%). First, the samples were analyzed under binocular microscope to identify zooplanktonic organisms. Next, a known volume $(0.03 \mathrm{ml})$

137 was pipetted onto a slide for microscopic observation $(\times 500)$. Items were identified using

138 diatoms and phytoplankton determination keys (Cupp, 1943; Prygiel and Coste, 2000).

139 Diatom volumes were estimated from literature data (Padisak and Adrian, 1999) and

140 zooplankton volumes were calculated from their length. The volumetric percentage was then

141 estimated for each item identified. 
Pasquaud, S. etal. Determination of fish trophic levels in an estuarine system

Estuarine Coastal and Shelf Science, $n^{\circ}$ 86. p. 237-246. 2010

http://www.sciencedirect.com/science?_ob=PublicationURL\&_tockey=\%23TOC\%236776\%232010\%23999139997\%231578281\%23FLA\%23\& cdi=

\subsection{Prey feeding ecology}

A bibliographic review was carried out to identify general feeding ecology of benthic prey (molluscs, annelid polychaetes and crabs), hyperbenthic prey (amphipods, isopods and

fish feeding ecology was estimated from the stomach content analysis results obtained in the present study and a published work (Pasquaud et al., 2008).

\subsection{Available data}

153 different pelagic nutritive pools during the considered period were chosen, one detritivorous

162 Eurytemora affinis and the other phytoplanktivorous Acartia spp. The averaged $\delta^{15} \mathrm{~N}$

163 signature of a benthic primary consumer, Cerastoderma edule, was used to characterize the 164 benthic baseline. 
Pasquaud, S. etal. Determination of fish trophic levels in an estuarine system Estuarine Coastal and Shelf Science, $n^{\circ}$ 86. p. 237-246. 2010

http://www.sciencedirect.com/science?_ob=PublicationURL\&_tockey=\%23TOC\%236776\%232010\%23999139997\%231578281\%23FLA\%23\&_cdi=

Fish trophic level (TL) was estimated as: $T L=\left[\left(\delta^{15} N_{p r e d}-\delta^{15} N_{b a s e}\right) / \Delta \delta^{15} N\right]+T L_{b a s e}$, where $\delta^{15} N_{\text {pred }}$ is the $\delta^{15} N$ signature of the predator in question, $\delta^{15} N_{\text {base }}$ is the $\delta^{15} N$ signature of a representative baseline for the predator and $T L_{\text {base }}$ is the trophic level of that baseline.

Primary consumers (Eurytemora affinis, Acartia spp. and Cerastoderma edule) were used for that baseline. So, $T L_{\text {base }}$ is equal to $2 . \Delta \delta^{15} N$ represents the trophic fractionation of $\delta^{15} \mathrm{~N}$, estimated at 3.4\%o (Post, 2002).

The fish preys feed on benthic and/or pelagic food chains (phytoplanktonic and/or detritic) and/or intermediate food chains (mixing of the two pelagic sources), determined from their feeding ecology. The fish species or size class studied present different diets. Thus from the knowledge of the food chains, we estimated for each fish predator group the $\delta^{15} \mathrm{~N}_{\text {base}}$, calculated as: $\delta^{15} N_{\text {base }}=\left(\% V_{B} \times \delta^{15} N_{B}+\% V_{H} \times \delta^{15} N_{H}+\% V_{D} \times \delta^{15} N_{D}+\% V_{I} \times \delta^{15} N_{I}\right) / 100$, where $\% \mathrm{~V}$ is the volumetric percentage of the prey $\mathrm{B}, \mathrm{H}, \mathrm{D}$ or I in the stomachs of a predator; B groups together all the prey feeding almost exclusively on the benthic food chain, $\mathrm{H}$ the prey feeding almost exclusively on the phytoplanktonic food chain, D the prey feeding almost exclusively on the detritic (pelagic) food chain, and I the prey feeding both on detritic and phytoplanktonic food chains.

\section{Results}

\subsection{Fish trophic ecology}


Pasquaud, S. etal. Determination of fish trophic levels in an estuarine system Estuarine Coastal and Shelf Science, $n^{\circ}$ 86. p. 237-246. 2010

http://www.sciencedirect.com/science?_ob=PublicationURL\&_tockey=\%23TOC\%236776\%232010\%23999139997\%231578281\%23FLA\%23\& cdi=

A large proportion of Liza ramada stomach contents was composed of organic debris

$192(\% \mathrm{~V}=86.53 \%)$. The rest was predominantly micro-algae in volume (essentially diatoms). (72.62\%) and the isopod Synidotea laticauda (11.68\%). S. solea fed more on the polychaetes Neanthes succinea (13.69\%) and Pectinaria koreni (12.02\%), the amphipods Gammarus spp. (19.46\%) and the shrimp Crangon crangon (10.35\%). Some vegetal debris (11.59\%) was found in its diet. their stomach contents consisted of Gammarus spp. (66.67\%) and the mysid Neomysis integer $201(26.19 \%)$.

All other species (Dicentrarchus labrax, Argyrosomus regius, Anguilla anguilla and Dicentrarchus punctatus) had a more diversified diet, feeding from the supra-, epibenthic and pelagic compartments on organisms such as amphipods, isopods, shrimps and copepods. They also are ichtyophagous. Large and small A. regius fed especially on Gammarus spp. 206 (respectively 14.92 and $11.87 \%$ ), C. crangon (35.76 and 17.96\%) and N. integer (12.15 and 207 17.16\%). Moreover, small A. regius consumed the mysids $M$. slabberi $(23.52 \%)$ and fish 208 larvae (20.78\%), whereas large A. regius fed on the shrimp Palaemon spp. (13.02\%). S. 209 laticauda was the preferential prey for large D. labrax (11.90\%), A. anguilla (25.59\%) and D. punctatus $(44.30 \%)$. The other preferential prey of D. punctatus was M. slabberi $(18.37 \%)$.

211 The $\operatorname{diet}$ of A. anguilla was also composed of Gammarus spp. (33.71\%) and Palaemon spp. 212 (12.75\%). Large D. labrax had the most diversified diet, eating many preys such as 213 Gammarus spp. (38.89\%), C. crangon (11.72\%), N. integer (12.89\%), copepods (12.50\%) 214 and fish (12.10\%). Finally, small D. labrax did not have the same diet as large individuals. 
Pasquaud, S. etal. Determination of fish trophic levels in an estuarine system

Estuarine Coastal and Shelf Science, $n^{\circ}$ 86. p. 237-246. 2010

http://www.sciencedirect.com/science?_ob=PublicationURL\&_tockey=\%23TOC\%236776\%232010\%23999139997\%231578281\%23FLA\%23\&_cdi=

215 Their stomach contents were composed of a large proportion of C. crangon (25\%), Palaemon

216 spp. (28.30\%), Acartia spp. (16.67\%) and fish (16.67\%).

218 determined (\%V>10\%; Table 2; Fig. 2).

\subsection{Prey trophic ecology}

A bibliographic review provides information on prey trophic ecology in the Gironde estuary or in similar estuarine systems (Table 3).

Organisms living on or in the sediment have diverse types of food habits: bivalves are suspension feeders (C. edule), deposit feeders (Macoma balthica) or grazers (Littorina saxatilis); polychaeta are carnivororous (Nephtys spp. or Neanthes spp.) or deposit feeders (Polydora spp., Notomastus latericeus, Heteromastus filiformis, Pectinaria koreni) and crabs

(Bathyporeia spp and Corophium volutator), shrimps (C. crangon) and copepods (Acanthocyclops trajani) also live on the sediment. However, all these species also use the sediment as a source of organic matter. In the pelagic compartment, organisms feed on phytoplankton, detritus or both. A few organisms, such as M. slabberi, Schistomysis spp., exclusively on detritus at the food web baseline. Most of the pelagic organisms consume both 236 phytoplankton and detritus (e.g. Euterpina acutifons, the crustacean larvae). 
Pasquaud, S. etal. Determination of fish trophic levels in an estuarine system

Estuarine Coastal and Shelf Science, $n^{\circ}$ 86. p. 237-246. 2010

http://www.sciencedirect.com/science?_ob=PublicationURL\&_tockey=\%23TOC\%236776\%232010\%23999139997\%231578281\%23FLA\%23\&_cdi=

3.3. Fish trophic levels

The characterization of fish and prey diets gives a good picture of the Gironde food

web (Fig. 2). It highlights the fact that the fish species studied use diverse sources of organic

matter by eating prey with different food habits. Moreover, from the feeding ecology information of preys and their $\delta^{15} \mathrm{~N}$ values, we observed an enrichment of the $\delta^{15} \mathrm{~N}$ signatures for the benthic species compared to the pelagic ones for an equivalent trophic position. In addition, an organism feeding on a detritic pelagic source got a higher $\delta^{15} \mathrm{~N}$ signatures compared to the ones using a phytoplanktonic source.

To identify a $\delta^{15} \mathrm{~N}_{\text {base }}$ for each fish group (genus, species or size class), the relative

250 proportion of each category of prey (B, H, D, I; cf. definitions part 2.6) in the diet was

251 estimated (Table 4). All the fish fed on both pelagic and benthic food chains, but in different proportions. For example, Pomatoschistus spp. ate only $3.57 \%$ of benthic prey whereas small chain. 0.39\% and for E. affinis (pelagic/detritic food chain) and Acartia spp. $10.70 \pm 0.50 \%$ for Pomatoschistus spp. and $13.60 \pm 0.12 \%$ for large D. labrax. 
Pasquaud, S. etal. Determination of fish trophic levels in an estuarine system Estuarine Coastal and Shelf Science, $n^{\circ}$ 86. p. 237-246. 2010

http://www.sciencedirect.com/science?_ob=PublicationURL\&_tockey=\%23TOC\%236776\%232010\%23999139997\%231578281\%23FLA\%23\& cdi=

punctatus and large A. regius (3.58). L. ramada (2.87), and Pomatoschistus spp. (3.14) were

266 found at the lower TL. Small A. regius and D. labrax and benthic fish S. solea and P. flesus

267 were at the intermediate position, at $\mathrm{TL}=3.15, \mathrm{TL}=3.43 ; \mathrm{TL}=3.30$ and $\mathrm{TL}=3.36$

268 respectively.

\section{Discussion}

\subsection{Trophic web of the Gironde estuary}

A precise estimation of fish trophic levels based on $\delta^{15} \mathrm{~N}$ values requires a good knowledge of the trophic web in order to characterize the different nutritive pools at the base of the system and to describe food linkages allow us to distinguish pelagic food chains from benthic ones (Vander Zanden and Rasmussen, 1999; Mc Cuthan et al., 2003).

bibliographic data, this time was estimated for fish to their warm growth period. Nevertheless,

281 this time is species and life-stage specific (e.g. Miller, 2006; Guelinckx et al., 2007). It will be interesting to complete this study by an experimental approach to define precisely the different turnover times.

Fish stomach content analyses were carried out the warm period and enabled us to identify qualitatively and quantitatively the different preys consumed by each fish group 286 studied. For both small and large groups of D. labrax, D. punctatus and L. ramada, the number of samples was reduced and/or limited to a restricted part of the period studied compared to other species, which led to less accurate results. Nevertheless, they were 
Pasquaud, S. etal. Determination of fish trophic levels in an estuarine system Estuarine Coastal and Shelf Science, $n^{\circ}$ 86. p. 237-246. 2010

http://www.sciencedirect.com/science?_ob=PublicationURL\&_tockey=\%23TOC\%236776\%232010\%23999139997\%231578281\%23FLA\%23\&_cdi=

addition, the trophic positions of these species obtained in that study are coherent with the description of their feeding ecology (Cf. following paragraph).

The general diet trends in their preys have been characterized from bibliographic data, mainly coming from Gironde estuary, to estimate the origin and the importance of each source for fish groups. Due to available isotopic data, one benthic baseline and two pelagic ones were distinguished. The knowledge of food chains and the $\delta^{15} \mathrm{~N}$ data of different compartments confirm the isotopic enrichment in benthic species compared to pelagic ones for an equivalent trophic position and also highlight an enrichment of the detritic pelagic chains compared to phytoplanktonic ones. Recycling processes of the detritic organic matter could explained these enrichments (Hughes et al., 2000; David et al., 2006).

Considering the pelagic chains, a prey may not have a clear detritic or phytoplanktonic origin, but rather have a mixed origin of both. For zooplanktonic species which feed on the two sources, an intermediate source has been attributed to them. It would be interesting to determine the relative importance of these sources for these species. Fatty acids would allow an identification of the different nutritive pools and produce a better estimate (David et al., 2006). However, the differentiation of the diverse pelagic sources described in the present work provides a realistic estimation of the fish trophic levels and of the importance of the phytoplanktonic source in the functioning of the system, which may be underestimated in previous studies.

During the warm period, the trophic organization of the Gironde appears to be based both on detritic and phytoplanktonic sources. Moreover, the pelagic organic matter sources seem to be more used than benthic ones. These observations on the functioning of the Gironde confirms the assumption put forward for this period of the year in a previous work using a mass-balanced trophic model (Lobry et al., 2008). 
Pasquaud, S. etal. Determination of fish trophic levels in an estuarine system

Estuarine Coastal and Shelf Science, $n^{\circ}$ 86. p. 237-246. 2010

http://www.sciencedirect.com/science?_ob=PublicationURL\&_tockey=\%23TOC\%236776\%232010\%23999139997\%231578281\%23FLA\%23\&_cdi=

4.2. Validity of the fish trophic levels obtained

By describing the bottom of the food chains and their sources we were able to

calculate the trophic levels of some main fish groups (species, genus or size class) in the

Gironde estuary from $\delta^{15} \mathrm{~N}$ values. The data from fish stomach content analyses obtained in

the nitrogen isotopic integrative period, or part of this period, led to a discussion about the validity of results.

In this study, L. ramada presents the lowest trophic level. Its feeding ecology differs

from that of other species as it consumes a high level of primary producers (micro-algae) and

detritus. Its grazing behaviour in brackish water, as previously described in other estuarine and coastal systems (Laffaille et al., 2002; Almeida, 2003), is confirmed here by its diet composed principally of benthic diatoms such as Coscinodiscus, Melosira, Raphoneis, Girosigma or Navicula (Almeida et al., 1993; Laffaille et al., 2002; Almeida, 2003). have intermediate trophic levels. The genus Pomatoschistus is described in this study as a small crustacean feeder, which is in agreement with a previous work on the Gironde

331 (Pasquaud et al., 2004) or other estuaries (e.g. Hamerlynck and Cattrijsse, 1994; Salgado et al., 2004; Leitão et al., 2006). P. flesus feeds especially on primary consumers, including a very large quantity of molluscs $(C$. edule) which were not found in their stomach contents the previous year (Pasquaud et al., 2008). Several studies (e.g. Summers, 1980; Hampel et al., 2005 ) indicate that the diet of $P$. flesus is very flexible, depending on benthic prey availability

336 in the environment. However, some authors emphasize this fish species' strong preference for molluscs (Jones, 1962; Vinagre et al., 2008). S. solea tends to eat carnivorous prey such as 338 polychaetes, Gammarus spp. and some decapods, as previously described in estuaries

339 (Vinagre et al., 2005; Pasquaud et al., 2008). The diet of the two flatfish species is 
Pasquaud, S. etal. Determination of fish trophic levels in an estuarine system Estuarine Coastal and Shelf Science, $n^{\circ}$ 86. p. 237-246. 2010

http://www.sciencedirect.com/science?_ob=PublicationURL\&_tockey=\%23TOC\%236776\%232010\%23999139997\%231578281\%23FLA\%23\&_cdi=

distinguished from that of Pomatoschistus by fish consumption and this may explain their

341 higher trophic levels. The lower trophic level of S. solea compared to $P$. flesus may be due to

342 the fact that vegetal debris is found in its stomach contents.

A. anguilla, D. punctatus, D. labrax and A. regius have the highest trophic levels.

344 They could be considered as the top predators of this system because of their carnivorous

345 feeding behaviour, feeding on a high diversity of crustaceans (amphipods, isopods, shrimps,

346 mysids), and especially because of their piscivorous trend. The diets of these species show

347 similarities with the results of the previous year in the Gironde estuary (Pasquaud et al., 2008)

348 and with those observed in other estuarine systems (Costa, 1988; Cabral and Costa, 2001;

349 Cabral and Ohmert, 2001). The quantitative differences could be explained by variations in

350 prey availability in the environment.

351 This study also shows an increase in trophic levels in parallel with an increase in the 352 size of individuals for the two species tested, D. labrax and A. regius. The same observation

353 was made from the analysis of $\delta^{15} \mathrm{~N}$ values (Pasquaud et al., 2008). This result suggests that a

354 species can play different functions in the ecosystem and emphasizes the importance of

355 considering size criteria in studies of trophic dynamics (Garrison and Link, 2000).

356 Thus the trophic levels of fish groups, calculated from $\delta^{15} \mathrm{~N}$ values, are representative

357 of their feeding ecology. This method allows us to correct the work of Pasquaud et al. (2008),

358 and therefore redefine the trophic position of the benthic fish.

5. Conclusions

This study demonstrates the necessity of a good knowledge of estuarine trophic webs,

364 of organic matter, in order to calculate fish trophic levels from $\delta^{15} \mathrm{~N}$ values and validate them. 
Pasquaud, S. etal. Determination of fish trophic levels in an estuarine system Estuarine Coastal and Shelf Science, $n^{\circ}$ 86. p. 237-246. 2010

http://www.sciencedirect.com/science?_ob=PublicationURL\&_tockey=\%23TOC\%236776\%232010\%23999139997\%231578281\%23FLA\%23\&_cdi=

Due to the considerable variability of these systems, it is essential to use

366 complementarily stable isotope and stomach contents analyses during the whole integration

367 period in fish. With this method, the variability of the feeding ecology during the considered

368 period is taken into account and a possible inter-annual variability in the feeding ecology of

369 some species (e.g. P. flesus) is palliated.

370 This approach developed to identify fish trophic levels in estuaries appears particularly

371 appropriate, giving more accurate results than those produced by the Ecopath model

372 developed in the Gironde estuary (see Lobry et al., 2008). This type of data could help to

373 validate trophic models (Dame and Christian, 2008).

374 For future research, it would be interesting to estimate more precisely the different

375 matter fluxes at the food web base and to study in details the recycling processes in order to

376 see the relative importance of the sources in the system and thus obtain a better understanding

377 of the functioning of estuarine fish food webs. 
Pasquaud, S. etal. Determination of fish trophic levels in an estuarine system Estuarine Coastal and Shelf Science, $n^{\circ}$ 86. p. 237-246. 2010

http://www.sciencedirect.com/science?_ob=PublicationURL\&_tockey=\%23TOC\%236776\%232010\%23999139997\%231578281\%23FLA\%23\&_cdi=

\section{Acknowledgements}

This investigation was supported by the French Institute of Agricultural and

381 Environmental Engineering Research (Cemagref). The authors would like to thank Maria

382 Cellamare (Cemagref-Bordeaux), Maud Cottet (Cemagref-Bordeaux), Michel Coste

383 (Cemagref-Bordeaux), Nicolas Savoye (University of Bordeaux 1) and Pierre Richard

384 (CNRS-CRELA, l'Houmeau). 
Pasquaud, S. etal. Determination of fish trophic levels in an estuarine system

Estuarine Coastal and Shelf Science, $n^{\circ}$ 86. p. 237-246. 2010

http://www.sciencedirect.com/science?_ob=PublicationURL\&_tockey=\%23TOC\%236776\%232010\%23999139997\%231578281\%23FLA\%23\&_cdi=

\section{References}

387 Akin, S., Winemiller, K.O., 2008. Body size and trophic position in a temperature estuarine

388 food web. Acta Oecologica-International Journal of Ecology 33, 144-153.

389 Almeida, P.R., 2003. Feeding ecology of Liza ramada (Risso, 1810) (Pisces, Mugilidae) in a

390 south-western estuary of Portugal. Estuarine, Coastal and Shelf Science 57, 313-323.

391 Almeida, P.R., Moreira, F., Costa, J.L., Assis, C.A., Costa, M.J., 1993. The feeding strategies

392 of Liza ramada (Risso, 1826) in fresh and brackish water in the River Tagus, Portugal.

393 Journal of Fish Biology 42, 95-107.

394 Bachelet, G., 1981. Données préliminaires sur l'organisation trophique d'un peuplement

395 benthique marin. Vie et Milieux 31, 205-213.

396 Cabral, H., Costa, M.J., 2001. Abundance, feeding ecology and growth of 0-group sea bass,

397 Dicentrarchus labrax, within the nursery areas of the Tagus estuary. Journal of the Marine

398 Biological Association of the United Kingdom 81, 679-682.

399 Cabral, H.N., Ohmert, B., 2001. Diet of juvenile meagre, Argyrosomus regius, within the

400 Tagus estuary. Cahiers de Biologie Marine 42, 289-293.

401 Cammen, L.M., 1980. A Method for Measuring Ingestion Rate Deposit Feeders and its Use 402 with the Polychaete Nereis succinea. Estuaries 3, 55-60.

403 Cannicci, S., Gomei, M., Boddi, B., Vannini, M., 2002. Feeding Habits And Natural Diet of 404 the Intertidal Crab Pachygrapsus marmoratus: Opportunistic Browser or Selective Feeder?

405 Estuarine, Coastal and Shelf Science 54, 983-1001.

406 Castel, J., Bachelet, G., Rochard, E., Elie, P., 1994. La biologie de l'estuaire, Estuaire de la

407 Gironde, livre blanc. Agence de l'Eau Adour Garonne, IFREMER, pp. 115. 
Pasquaud, S. etal. Determination of fish trophic levels in an estuarine system Estuarine Coastal and Shelf Science, $n^{\circ}$ 86. p. 237-246. 2010

http://www.sciencedirect.com/science?_ob=PublicationURL\&_tockey=\%23TOC\%236776\%232010\%23999139997\%231578281\%23FLA\%23\&_cdi=

Church, M.R., Ebersole, J.L., Rensmeyer, K.M., Couture, R.B., Barrows, F.T., Noakes,

D.L.G., 2009. Mucus: a new tissue fraction for rapid determination of fish diet switching

using stable isotope analysis. Canadian Journal of Fisheries and Aquatic Sciences 66, 1-5.

Cohen, A.N., Carlton, J.T., Fountain, M.C., 1995. Introduction, dispersal and potential $122,225-237$.

414 Costa, M.J., 1988. Ecologie alimentaire des poissons de l'estuaire du Tage. Cybium 12, 301320.

Cupp, E.E., 1943. Marine plankton diatoms of the west coast of North America. University of California press Berkeley and Los Angeles.

418 Dame, J.K., Christian, R.R., 2008. Evaluation of ecological network analysis: Validation of 419 output. Ecological Modelling 210, 327-338.

420 Davenport, S.R., Bax, N.J., 2002. A trophic study of a marine ecosystem off southeasten 421 Australia using stable isotopes of carbon and nitrogen. Canadian Journal of Fisheries and 422 Aquatic Sciences 59, 514-530.

423 David, V., Sautour, B., Chardy, P., 2007. Successful colonization of the calanoid copepod 424 Acartia tonsa in the oligo-mesohaline area of the Gironde estuary (SW France) - Natural or anthropogenic forcing? Estuarine Coastal and Shelf Science 71, 429-442.

426 David, V., Sautour, B., Galois, R., Chardy, P., 2006. The paradox high zooplankton biomass427 low vegetal particulate organic matter in high turbidity zones: What way for energy transfer? 428 Journal of Experimental Marine Biology and Ecology 333, 202-218.

429 De Niro, M.J., Epstein, S., 1978. Influence of diet on the distribution of carbon isotopes in 430 animals. Geochimica et Cosmochimica Acta 42, 495-506.

431 De Niro, M.J., Epstein, S., 1981. Influence of the diet on the distribution of nitrogen isotopes 432 in animals. Geochimica et Cosmochimica Acta 45, 341-351. 
Pasquaud, S. etal. Determination of fish trophic levels in an estuarine system Estuarine Coastal and Shelf Science, $n^{\circ}$ 86. p. 237-246. 2010

http://www.sciencedirect.com/science?_ob=PublicationURL\&_tockey=\%23TOC\%236776\%232010\%23999139997\%231578281\%23FLA\%23\&_cdi=

433 Fauchald, K., Jumars, P.A., 1979. The diet of worms: a study of polychaete feeding guilds.

434 Oceanographic marine biology. Annual Review 17, 193-284.

435 Fockedey, N., Mees, J., 1999. Feeding of the hyperbenthic mysid Neomysis integer in the

436 maximum turbidity zone of the Elbe, Westerschelde and Gironde estuaries. Marine Systems

$437 \quad 22,207-228$.

438 Fry, B., Sherr, E.B., 1984. $\delta^{13} \mathrm{C}$ measurements as indicators of carbon flow in marine and

439 freshwater ecosystems. Contributions in Marine Science 27, 13-47.

440 Garrison, L.P., Link, J.S., 2000. Dietary guild structure of the fish community in the

441 Northeast United States continental shelf ecosystem. Marine Ecology Progress Series 202,

$442 \quad 231-240$.

443 Gerdol, V., Hughes, R.G., 1994. Feeding behaviour and diet of Corophium volutator in an

444 estuary in southeastern England. Marine Ecology Progress Series 114, 103-108.

445 Grall, J., Le Loc'h, F., Guyonnet, B., Riera, P., 2006. Community structure and food web

446 based on stable isotopes $\left(\delta^{15} \mathrm{~N}\right.$ and $\left.\delta^{13} \mathrm{C}\right)$ analysis of a North Eastern Atlantic maerl bed.

447 Journal of Experimental Marine Biology and Ecology 338, 1-15.

448 Grosholz, E.D., Ruiz, G.M., 1996. Predicting the impact of introduced marine species:

449 Lessons from the multiple invasion of the European green crab Carcinus maenas. Biological

450 Conservation 78, 59-66.

451 Guelinckx, J., Maes, J., Van Den Driessche, P., Geysen, B., Dehairs, F., Ollevier, F., 2007.

452 Changes in delta C-13 and delta N-15 in different tissues of juvenile sand goby

453 Pomatoschistus minutus: a laboratory diet-switch experiment. Marine Ecology-Progress

454 Series 341, 205-215.

455 Hamerlynck, O., Cattrijsse, A., 1994. The food of Pomatoschistus minutus (Pisces, Gobiidae)

456 in Belgian coastal waters, and a comparison with the food of its potential competitor $P$.

457 lozanoi. Journal of Fish Biology 44, 753-771. 
Pasquaud, S. etal. Determination of fish trophic levels in an estuarine system Estuarine Coastal and Shelf Science, $n^{\circ}$ 86. p. 237-246. 2010

http://www.sciencedirect.com/science?_ob=PublicationURL\&_tockey=\%23TOC\%236776\%232010\%23999139997\%231578281\%23FLA\%23\&_cdi=

Hampel, H., Cattrijsse, A., Elliott, M., 2005. Feeding habits of young predatory fishes in marsh creeks situated along the salinity gradient of the Schelde estuary, Belgium and The Netherlands. Helgoland Marine Research 59, 151-162.

Herman, P.M.J., Middelburg, J.J., Widdows, J., Lucas, C.H., Heip, C.H.R., 2000. Stable isotopes as trophic tracers: combining field sampling and manipulative labelling of food resources for macrobenthos. Marine Ecology Progress Series 204, 79-92.

Hesslein, R.H., Capel, M.J., Fox, D.E., Hallard, K.A., 1991. Stable isotopes of sulfur, carbon, and nitrogen as indicators of trophic level and fish migration in the lower Mackenzie river basin, Canada. Canadian Journal of Fisheries and Aquatic Sciences 48, 2258-2265.

Hesslein, R.H., Hallard, K.A., Ramlal, P., 1993. Replacement of Sulfur, carbon and nitrogen in tissue of Growing broad Whitefish (Coregonus nasus) in response to a change in diet traced by delta $34 \mathrm{~S}$, delta $13 \mathrm{C}$ and delta $15 \mathrm{~N}$. Canadian Journal of Fisheries and Aquatic Sciences 50, 2071-2076.

Hughes, J.E., Deegan, L.A., Peterson, B.J., Holmes, R.M., Fry, B., 2000. Nitrogen flow through the food web in the oligohaline zone of a new England estuary. Ecology 81, 433-452. Hyslop, E.J., 1980. Stomach contents analysis - a review of methods and their application. Journal of Fish Biology 17, 411-429.

Jones, N.S., 1962. The bottom fauna and the food of flatfish of the Cumberland Coast. Journal of Animal Ecology 21, 182-205.

Kwak, T., Zedler, J.B., 1997. Food web analysis of southern California coastal wetlands using multiple stable isotopes. Oecologia 110, 262-277.

Laffaille, P., Feunteun, E., Lefebvre, C., Radureau, A., Sagan, G., Lefeuvre, J.-C., 2002. Can Thin-lipped Mullet Directly Exploit the Primary and Detritic Production of European Macrotidal Salt Marshes? Estuarine, Coastal and Shelf Science 54, 729-736. 
Pasquaud, S. etal. Determination of fish trophic levels in an estuarine system Estuarine Coastal and Shelf Science, $n^{\circ}$ 86. p. 237-246. 2010

http://www.sciencedirect.com/science?_ob=PublicationURL\&_tockey=\%23TOC\%236776\%232010\%23999139997\%231578281\%23FLA\%23\&_cdi=

482

483

484

485

486

487

488

489

490

491

492

493

494

495

496

497

498

499

500

501

502

503

504

505

Laurand, S., Riera, P., 2006. Trophic ecology of the supralittoral rocky shore (Roscoff,

France): A dual stable isotope $\left(\delta^{13} \mathrm{C}, \delta^{15} \mathrm{~N}\right)$ and experimental approach. Journal of Sea

Research 56, 27-36.

Leitão, R., Martinho, E., Neto, J.M., Cabral, H., Marques, J.C., Pardal, M.A., 2006. Feeding ecology, population structure and distribution of Pomatoschistus microps (Kroyer, 1838) and Pomatoschistus minutus (Pallas, 1770) in a temperate estuary, Portugal. Estuarine Coastal and Shelf Science 66, 231-239.

Lobry, J., David, V., Pasquaud, S., Lepage, M., Sautour, B., Rochard, E., 2008. Diversity and stability of an estuarine trophic network. Marine Ecology Progress Series 358, 13-25.

Marchand, J., 1981. Observations sur l'écologie de Crangon crangon (Linné) et Palaemon longirostris H. Milne Edwards (Crustacea, Decapoda, Natantia) dans l'estuaire interne de la Loire (France). Vie et Milieu 31, 83-92.

Mc Cuthan, J.H., Lewis, W.M., Kendall, C., Mc Grath, C.C., 2003. Variation in trophic shift for stable isotope ratios of carbon, nitrogen, and sulfur. Oikos 102, 378-390.

Miller, T.W., 2006. Tissue-specific response of delta N-15 in adult Pacific herring (Clupea pallasi) following an isotopic shift in diet. Environmental Biology of Fishes 76, 177-189.

Minagawa, M., Wada, E., 1984. Stepwise enrichment of ${ }^{15} \mathrm{~N}$ along food chains: further evidence and the relation between $\delta^{15} \mathrm{~N}$ and animal age. Geochimica et Cosmochimica Acta $48,1135-1140$.

Mouny, P., Dauvin, J.C., Bessineton, C., Elkaim, B., Simon, S., 1998. Biological components from the Seine estuary: first results. Hydrobiologia 374, 333-347.

Ólafsson, E.B., Persson, L.-E., 1986. Distribution, life cycle and demography in a brackish water population of the isopod Cyathura carinata (Kröyer) (Crustacea). Estuarine, Coastal and Shelf Science 23, 673-687. 
Pasquaud, S. etal. Determination of fish trophic levels in an estuarine system Estuarine Coastal and Shelf Science, $n^{\circ}$ 86. p. 237-246. 2010

http://www.sciencedirect.com/science?_ob=PublicationURL\&_tockey=\%23TOC\%236776\%232010\%23999139997\%231578281\%23FLA\%23\&_cdi=

Padisak, J., Adrian, R., 1999. Biovolumen. In: Tümpling, W. and Friedrich, G. (Eds),

507 Biologische Gewässeruntersuchung. Fisher, G., pp. 334-368.

508 Pasquaud, S., Elie, P., Jeantet, C., Billy, I., Martinez, P., Girardin, M., 2008. A preliminary

509 investigation of the fish food web in the Gironde estuary, France, using dietary and stable

510 isotope analyses. Estuarine, Coastal and Shelf Science 78, 267-279.

511 Pasquaud, S., Girardin, M., Elie, P., 2004. Diet of gobies of the genus Pomatoschistus (P.

512 microps and P. minutus), in the Gironde estuary (France). Cybium 28, 99-106.

513 Perga, M.E., Gerdeaux, D., 2003. Using the $\delta^{13} \mathrm{C}$ and $\delta^{15} \mathrm{~N}$ of whitefish scales for

514 retrospective ecological studies: Changes in isotope signatures during the restoration of Lake

515 Geneva, 1980-2001. Journal of Fish Biology 63, 1197-1207.

516 Perga, M.E., Gerdeaux, D., 2005. 'Are fish what they eat' all year round? Oecologia 144, 598-

517606.

518 Persson, A., Hansoon, L.A., 1999. Diet shift in fish following competitive release. Canadian

519 Journal of Fisheries and Aquatic Sciences 56, 70-78.

520 Pillay, T.V.R., 1952. A critique of the methods of study of food of fishes. Journal of the

521 Zoological Society of India 4, 185-200.

522 Post, D.M., 2002. Using stable isotopes to estimate trophic position: Models, methods, and 523 assumptions. Ecology 83, 703-718.

524 Prygiel, J., Coste, M., 2000. Guide méthodologique pour la mise en œuvre de l'indice

525 biologique Diatomées. Agences de l'eau, MATE, Cemagref Bordeaux, 134 pp.

526 Salgado, J.P., Cabral, H.N., Costa, M.J., 2004. Feeding ecology of the gobies Pomatoschistus

527 minutus (Pallas, 1770) and Pomatoschistus microps (Kroyer, 1838) in the upper Tagus

528 estuary, Portugal. Scientia Marina 68, 425-434. 
Pasquaud, S. etal. Determination of fish trophic levels in an estuarine system Estuarine Coastal and Shelf Science, $n^{\circ}$ 86. p. 237-246. 2010

http://www.sciencedirect.com/science?_ob=PublicationURL\&_tockey=\%23TOC\%236776\%232010\%23999139997\%231578281\%23FLA\%23\&_cdi=

Sauriau, P.G., Mouret, V., Rince, J.P., 1989. Organisation trophique de la malacofaune

benthique non cultivée du bassin ostréicole de Marennes-Oléron. Oceanologica Acta 12, 193 -

204.

532 Sherwood, G.D., Rose, G.A., 2005. Stable isotope analysis of some representative fish and

533 invertebrates of the Newfoundland and Labrador continental shelf food web. Estuarine,

534 Coastal and Shelf Science 63, 537-549.

535 Sorbe, J.-C., 1983. Les décapodes natantia de l'estuaire de la Gironde (France). Contribution à

536 l'étude morphologique et biologique de Palaemon longirostris. H. Milne Edwards, 1837.

537 Crustaceana 44, 251-270.

538 Sottolichio, A., Castaing, P., 1999. A synthesis on seasonal dynamics of highly-concentrated

539 structures in the Gironde estuary. Comptes rendus de l'Académie des Sciences Série II

540 Fascicule a- Sciences de la Terre et des Planètes 329, 795-800.

541 Summers, R.W., 1980. The diet and feeding behaviour of the flounder Platichthys flesus (L.)

542 in the Ythan estuary, Aberdeeshire, Scotland. Estuarine and Coastal Marine Science 11, $217-$

543232.

544 Suring, E., Wing, S.R., 2009. Isotopic turnover rate and fractionation in multiple tissues of red 545 rock lobster (Jasus edwardsii) and blue cod (Parapercis colias): Consequences for ecological 546 studies. Journal of Experimental Marine Biology and Ecology 370, 56-63.

547 Thiébaut, E., Lagadeuc, Y., Olivier, F., Dauvin, J.C., Retière, C., 1998. Do hydrodynamic

548 factors affect the recruitment of marine invertebrates in a macrotidal area? Hydrobiologia $549 \quad 375-376,165-176$.

550 Tieszen, L.L., Boutton, T.W., Tesdahl, K.G., 1983. Fractionation and turnover of stable 551 carbon isotopes in animal tissues: implication for $\delta^{13} \mathrm{C}$ analysis of diet. Oecologia 57, 32-37. 
Pasquaud, S. etal. Determination of fish trophic levels in an estuarine system Estuarine Coastal and Shelf Science, $n^{\circ}$ 86. p. 237-246. 2010

http://www.sciencedirect.com/science?_ob=PublicationURL\&_tockey=\%23TOC\%236776\%232010\%23999139997\%231578281\%23FLA\%23\&_cdi=

Vander Zanden, M.J., Cabana, G., Rasmussen, J.B., 1997. Comparing trophic position of freshwater fish calculated using stable nitrogen isotope ratios $\left(\delta^{15} \mathrm{~N}\right)$ and literature dietary data. Canadian Journal of Fisheries and Aquatic Sciences 54, 1142-1158.

Vander Zanden, M.J., Rasmussen, J.B., 1999. Primary consumer $\delta^{13} \mathrm{C}$ and $\delta^{15} \mathrm{~N}$ and the trophic position of aquatic consumers. Ecology 80, 1395-1404.

Vinagre, C., Cabral, H., Costa, M.J., 2008. Prey selection by flounder, Platichthys flesus, in the Douro estuary, Portugal. Journal of Applied Ichthyology 24, 238-243.

Vinagre, C., Franca, S., Costa, M.J., Cabral, H.N., 2005. Niche overlap between juvenile flatfishes, Platichthys flesus and Solea solea, in a southern European estuary and adjacent coastal waters. Journal of Applied Ichthyology 21, 114-120.

Wada, E., Mizutani, H., Minagawa, M., 1991. The use of stable isotopes for food web analysis. Critical Reviews in Food Science and Nutrition 30, 361-371.

Wägele, J.W., Welsch, U., Müller, W., 1981. Fine structure and function of the digestive tract of Cyathura carinata (Krøyer) (Crustacea, Isopoda). Zoomorphology 98, 69-88.

West, J.M., Williams, G.D., Madon, S.P., Zedler, J.B., 2003. Integrating spatial and temporal variability into the analysis of fish food web linkages in Tijuana Estuary. Environmental Biology of Fishes 67, 297-309.

Wieking, G., Kröncke, I., 2005. Is benthic trophic structure affected by food quality? The Dogger Bank example. Marine Biology 146, 387-400.

Winemiller, K.O., Akin, S., Zeug, S.C., 2007. Production sources and food web structure of a temperate tidal estuary: integration of dietary and stable isotope data. Marine EcologyProgress Series 343, 63-76.

Ysebaert, T., Herman, P.M.J., 2002. Spatial and temporal variation in benthic macrofauna and relationships with environmental variables in an estuarine, intertidal soft-sediment environment. Marine Ecology Progress Series 244, 105-124. 
Pasquaud, S. etal. Determination of fish trophic levels in an estuarine system

Estuarine Coastal and Shelf Science, $n^{\circ}$ 86. p. 237-246. 2010

http://www.sciencedirect.com/science?_ob=PublicationURL\&_tockey=\%23TOC\%236776\%232010\%23999139997\%231578281\%23FLA\%23\& cdi=

\section{Captions}

Fig. 1. Map of the Gironde estuary showing the fish sampling stations (stars) for dietary and stable isotope analyses.

Fig. 2. Synthesis of the Gironde estuary trophic web knowledge during the investigation period. Relationships between fish (simple line box) and their preys (dashed box) result from data of fish stomach content analyses (present study). The thicker the arrow, the greater the trophic link. Relationships between preys and sources of organic matter (double lines box) were established from bibliographic work. Excepted for S. laticauda, all these data come from the Gironde estuary. The different compartments were localised according to their trophic position, from TL results for fish, from feeding ecology information for prey. The mean $\delta^{15} \mathrm{~N}$ signature $(\% \circ)$ of each taxon, obtained in that study, is indicated in grey.

Table 1. Size class and total number (n) of fish analysed for the Stable Isotope Analyses (SIA) and the Stomach Content Analyses (SCA).

Table 2. Volumetric percentage diet composition of fish collected during their growth period in the Gironde estuary; n: total number of full stomachs; *: small size class; **: large size class and bold type denotes preferential preys $(\% \mathrm{~V}>10 \%)$.

Table 3. Diet of the different preys examined in fish Stomach Content Analysis (SCA) and trophic chain to which preys belong.

Table 4. Volumetric percentage diet composition of fish species (or size class) on each trophic chain $(\% \mathrm{~V}=$ volumetric percentage of $-\mathrm{B}$ : preys dependent of the sediment as organic matter, 
Pasquaud, S. etal. Determination of fish trophic levels in an estuarine system Estuarine Coastal and Shelf Science, $n^{\circ}$ 86. p. 237-246. 2010

http://www.sciencedirect.com/science?_ob=PublicationURL\&_tockey=\%23TOC\%236776\%232010\%23999139997\%231578281\%23FLA\%23\&_cdi=

603 - P: preys dependent of the pelagic source, - H: preys dependent of the phytoplankton,- D:

604 preys dependent of the detritus, - I: preys dependent of the intermediate pelagic source), mean

$605 \delta^{15} \mathrm{~N}$ signatures (\%o, \pm Standard Deviation) of organisms, $\delta^{15} \mathrm{~N}_{\text {base }}$ estimation (\%o,) of the

606 trophic chain base to which fish species belong. TL: Trophic level of representative baseline

607 organisms and each fish species or size class. $*=$ small size class and $* *=$ large size class. 
Pasquaud, S. etal. Determination of fish trophic levels in an estuarine system

Estuarine Coastal and Shelf Science, $n^{\circ}$ 86. p. 237-246. 2010

http://www.sciencedirect.com/science?_ob=PublicationURL\&_tockey=\%23TOC\%236776\%232010\%23999139997\%231578281\%23FLA\%23\&_cdi=

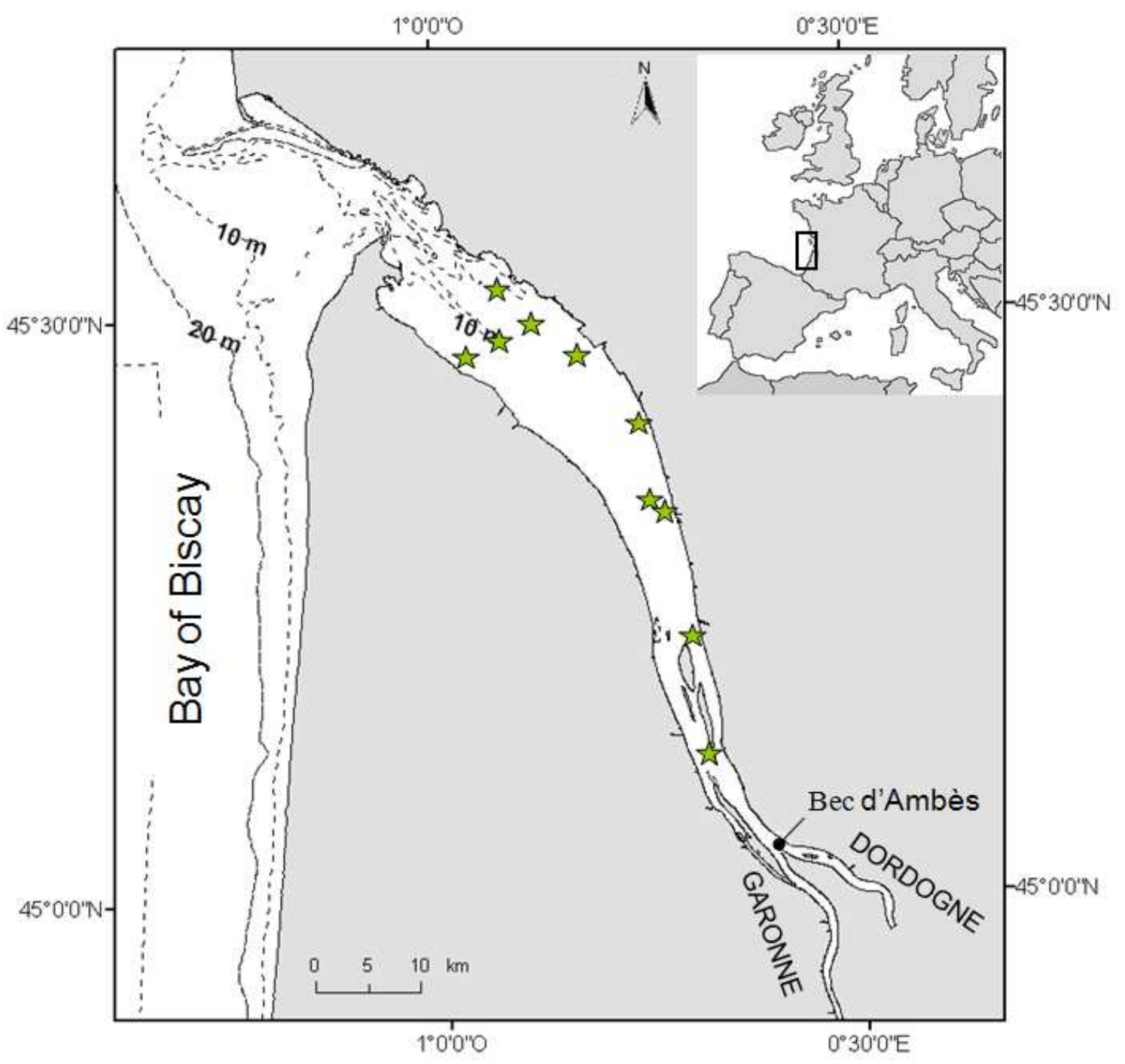

609 Fig. 1. 
Pasquaud, S. etal. Determination of fish trophic levels in an estuarine system

Estuarine Coastal and Shelf Science, $n^{\circ}$ 86. p. 237-246. 2010

http://www.sciencedirect.com/science?_ob=PublicationURL\&_tockey=\%23TOC\%236776\%232010\%23999139997\%231578281\%23FLA\%23\&_cdi=

610

TROPHIC

POSITION

611

612

613

614

615

616

617

618

619

620

621

622

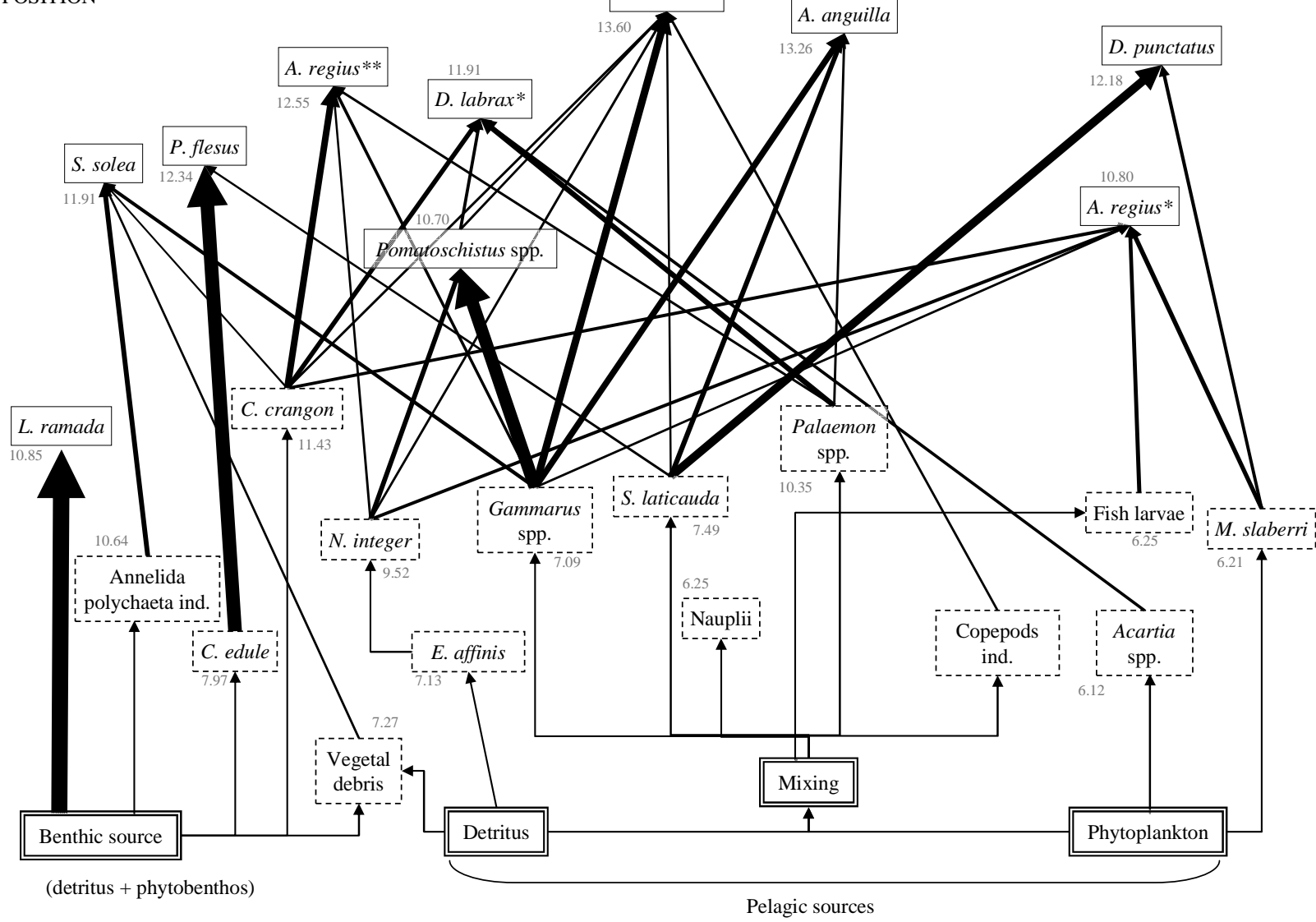

623 Fig. 2. 
Pasquaud, S. etal. Determination of fish trophic levels in an estuarine system

Estuarine Coastal and Shelf Science, $n^{\circ}$ 86. p. 237-246. 2010

http://www.sciencedirect.com/science?_ob=PublicationURL\&_tockey=\%23TOC\%236776\%232010\%23999139997\%231578281\%23FLA\%23\&_cdi=

624 Table 1.

\begin{tabular}{lcccc}
\hline Species & $\mathrm{n}(\mathrm{SCA})$ & $\begin{array}{c}\text { size class } \\
(\mathrm{mm}) \text { for SCA }\end{array}$ & $\mathrm{n}(\mathrm{SIA})$ & $\begin{array}{c}\text { size } \\
\text { class (mm) for } \\
\text { SIA }\end{array}$ \\
\hline Anguilla anguilla & 36 & $267-643$ & 21 & $267-760$ \\
Dicentrarchus labrax $* *$ & 13 & $195-231$ & 2 & $180-200$ \\
Dicentrarchus labrax $^{*}$ & 6 & $79-109$ & 4 & $70-100$ \\
Dicentrarchus punctatus $_{\text {Argyrosomus regius }}^{* *}$ & 13 & $75-183$ & 5 & $75-189$ \\
Argyrosomus regius $^{*}$ & 82 & $237-309$ & 9 & $220-300$ \\
Platichthys flesus $_{\text {Solea solea }}$ & 35 & $53-166$ & 11 & $54-160$ \\
Pomatoschistus spp. & 22 & $147-333$ & 11 & $121-333$ \\
Liza ramada & 52 & $117-197$ & 12 & $90-198$ \\
& 35 & $57-65$ & 7 & $29-65$ \\
& 17 & $65-112$ & 8 & $78-188$ \\
\hline
\end{tabular}

625 


\begin{tabular}{|c|c|c|c|c|c|c|c|c|c|c|}
\hline Species & 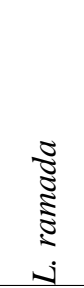 & $\begin{array}{l}0 \\
0 \\
0 \\
0 \\
ن \\
ن\end{array}$ & $\frac{\widetilde{v}}{2}$ & 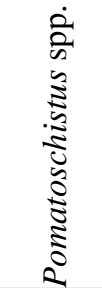 & $\frac{\sqrt{0}}{3}$ & $\begin{array}{l}* \\
0 \\
0 \\
0 \\
0 \\
0 \\
\end{array}$ & 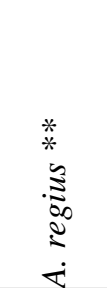 & $\begin{array}{c}0 \\
\vdots \\
0 \\
0 \\
0 \\
0 \\
\vdots \\
0 \\
0\end{array}$ & 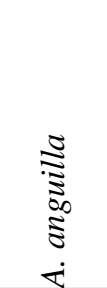 & $\begin{array}{c}* \\
* \\
0 \\
\vdots \\
0 \\
0 \\
0 \\
0\end{array}$ \\
\hline size $(\mathrm{mm})$ & $\begin{array}{l}65- \\
112\end{array}$ & $\begin{array}{l}117- \\
197\end{array}$ & $\begin{array}{c}147- \\
333\end{array}$ & $57-65$ & $\begin{array}{l}79- \\
109\end{array}$ & $\begin{array}{l}53- \\
166\end{array}$ & $\begin{array}{c}237- \\
309\end{array}$ & $\begin{array}{l}75- \\
183\end{array}$ & $\begin{array}{c}267- \\
643\end{array}$ & $\begin{array}{l}195- \\
231\end{array}$ \\
\hline $\mathrm{n}$ & 17 & 52 & 17 & 28 & 6 & 35 & 82 & 13 & 36 & 8 \\
\hline \multicolumn{11}{|l|}{ Bivalves } \\
\hline $\begin{array}{l}\text { Cerastoderma edule } \\
\text { Macoma balthica } \\
\text { Littorina saxatilis } \\
\text { Annelida polychaetes }\end{array}$ & & 0.10 & $\begin{array}{c}\mathbf{7 2 . 6 2} \\
0.53 \\
0.01\end{array}$ & & & & & & & \\
\hline Nereis spp. & & & & & 3.30 & & & 7.57 & & \\
\hline Hediste diversicolor & & 1.29 & & & & & & & & \\
\hline Neanthes succinea & & 13.69 & & & & & 0.40 & & & \\
\hline Polydora spp. & & 4.83 & & & & & & & & \\
\hline Nephtys spp. & & & 0.31 & & & & & & & \\
\hline Notomastus latericeus & & & 0.38 & & & & & & & \\
\hline Heteromastus filiformis & & & 0.19 & & & & & & & \\
\hline Pectinaria koreni & & 12.02 & & & & & & & & \\
\hline \multicolumn{11}{|l|}{ Crabs } \\
\hline Carcinus maenas & & 0.32 & & & & & & & 2.08 & \\
\hline Pachygrapsus marmoratus & & & & & & & & & 1.39 & \\
\hline $\begin{array}{l}\text { Liocarcinus spp. } \\
\text { Amphipods }\end{array}$ & \multicolumn{9}{|c|}{ Amphipods } & \\
\hline Gammarus spp. & & 19.46 & & 66.67 & & 11.87 & 14.92 & 8.24 & 33.71 & 38.89 \\
\hline Bathyporeia spp. & & 0.51 & & 3.57 & & & 0.05 & 0.15 & & \\
\hline Corophium volutator & & 3.61 & 5.88 & & & & & 1.87 & & \\
\hline \multicolumn{10}{|l|}{ Isopods } & \\
\hline Synidotea laticauda & & 4.83 & 11.68 & & & 2.37 & 8.13 & 44.30 & 25.59 & 11.90 \\
\hline Sphaeroma serratum & & & & & 9.23 & 3.25 & & & & \\
\hline Cyathura carinata & & 6.08 & 0.04 & & & & & & & \\
\hline Idotea spp. & & 1.48 & & & 0.18 & & & & & \\
\hline \multicolumn{11}{|l|}{ Shrimps } \\
\hline Crangon crangon & & 10.35 & & & 25.00 & 17.96 & 35.76 & & 7.40 & 11.72 \\
\hline \multicolumn{10}{|l|}{ Mysids } & \\
\hline Mesopodopsis slabberi & & & & & 0.33 & 23.52 & 3.88 & 18.37 & 0.10 & \\
\hline Neomysis integer & & & & 26.19 & & 17.16 & 12.15 & 3.31 & 9.10 & 12.89 \\
\hline \multicolumn{11}{|l|}{ Shistomysis spp. } \\
\hline Gastrosaccus spp. & & & & & & & 0.05 & & & \\
\hline Mysids undetermined & & & & & & & 0.95 & & 0.09 & \\
\hline \multicolumn{11}{|l|}{ Copepods ind. } \\
\hline Acartia spp. & 1.73 & & & & 16.67 & 0.03 & & & & \\
\hline Eurytemora affinis & & & & & & 0.63 & & & & \\
\hline Acanthocyclops trajani & & & & & & & & 8.33 & & \\
\hline Euterpina acutifrons & 2.60 & & & & & & & & & \\
\hline Copepods undetermined & 0.57 & & & & & & & & & 12.50 \\
\hline
\end{tabular}

Table 2 
Pasquaud, S. etal. Determination of fish trophic levels in an estuarine system

Estuarine Coastal and Shelf Science, $n^{\circ}$ 86. p. 237-246. 2010

http://www.sciencedirect.com/science?_ob=PublicationURL\&_tockey=\%23TOC\%236776\%232010\%23999139997\%231578281\%23FLA\%23\&_cdi=

628 Table 2 (continued)

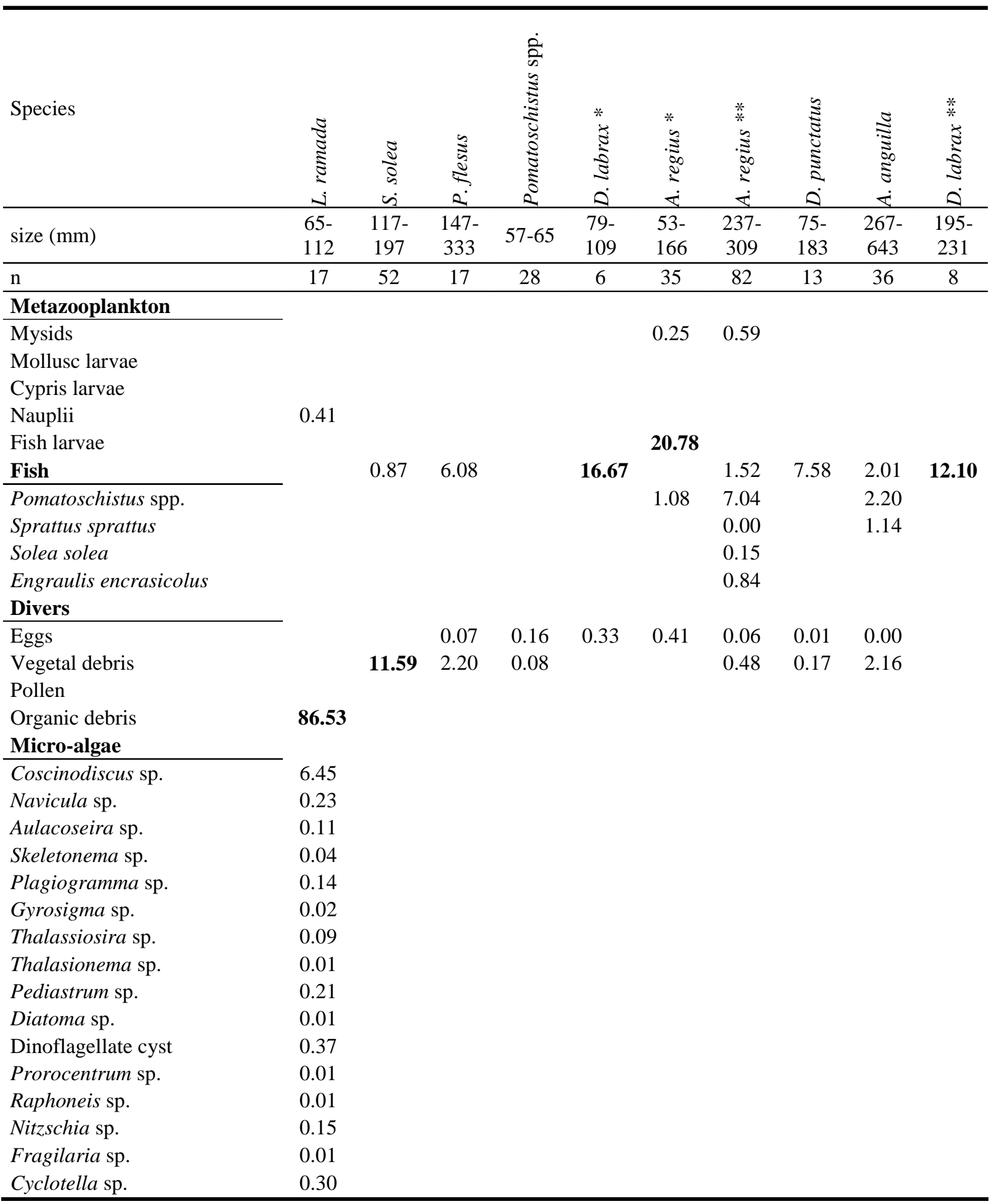




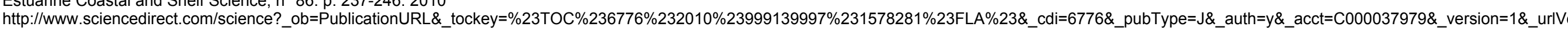

Table 3

\begin{tabular}{|c|c|c|c|c|}
\hline Species & Diet & References & $\begin{array}{l}\text { Gironde } \\
\text { data }(*)\end{array}$ & $\begin{array}{c}\text { Source of } \\
\text { organic matter }\end{array}$ \\
\hline \multicolumn{5}{|l|}{ Bivalves } \\
\hline Cerastoderma edule & active suspension feeder & Bachelet, 1981; Sauriau et al., 1989; Ysebaert \& Herman, 2002 & $*$ & sediment \\
\hline Macoma balthica & surface deposit and filter-feeder & Bachelet, 1981; Sauriau et al., 1989; Castel et al., 1994; Ysebaert \& Herman, 2002 & $*$ & sediment \\
\hline Littorina saxatilis & grazer & Laurand \& Riera, 2006 & & sediment \\
\hline Annelid polychaetes & & Bachelet, 1981 & $*$ & sediment \\
\hline Neanthes spp. & carnivorous, omnivorous & Fauchald \& Jumars, 1979; Cammen, 1980; Ysebaert \& Herman, 2002 & & sediment \\
\hline Hediste diversicolor & carnivorous, omnivorous & Fauchald \& Jumars, 1979; Ysebaert \& Herman, 2002 & & sediment \\
\hline Neanthes succinea & carnivorous, omnivorous & Fauchald \& Jumars, 1979; Cammen, 1980 & & sediment \\
\hline Polydora spp. & surface deposit feeder & Fauchald \& Jumars, 1979 & & sediment \\
\hline Nephtys spp. & carnivorous, omnivorous & Fauchald \& Jumars, 1979 & & sediment \\
\hline Notomastus latericeus & subsurface deposit feeder & Fauchald \& Jumars, 1979; Grall et al., 2006 & & sediment \\
\hline Heteromastus filiformis & subsurface deposit feeder & Fauchald \& Jumars, 1979; Ysebaert \& Herman, 2002 & & sediment \\
\hline Pectinaria koreni & subsurface deposit feeder & Fauchald \& Jumars, 1979; Thiébaut et al., 1998 & & sediment \\
\hline \multicolumn{5}{|c|}{ (1) } \\
\hline Carcinus maenas & carnivorous, omnivorous & Cohen et al., 1995; Grosholz \& Ruiz, 1996 & & sediment \\
\hline Pachygrapsus marmoratus & carnivorous, omnivorous & Cannicci et al., 2002 & & sediment \\
\hline $\begin{array}{l}\text { Liocarcinus spp. } \\
\text { Amphipods }\end{array}$ & carnivorous, omnivorous & Grall et al., 2006 & & $\begin{array}{l}\text { sediment } \\
\text { intermediate }\end{array}$ \\
\hline Gammarus spp. & carnivorous, omnivorous & Unpublished data & * & intermediate \\
\hline Bathyporeia spp. & suspension and surface deposit feeder & Herman et al., 2000; Wieking \& Kröncke, 2005 & & sediment \\
\hline Corophium volutator & deposit and filter feeder & Castel et al., 1994; Gerdol \& Hugues, 1994, Ysebaert \& Herman, 2002 & $*$ & sediment \\
\hline \multicolumn{5}{|l|}{ Isopods } \\
\hline Synidotea laticauda & phytoplanktivorous, detritivorous & & & intermediate \\
\hline Sphaeroma serratum & phytoplanktivorous, detritivorous & & & sediment \\
\hline Cyathura carinata & carnivorous & Wägele et al., 1981; Olafsson \& Persson, 1986 & & sediment \\
\hline $\begin{array}{l}\text { Idotea spp. } \\
\text { Shrimps }\end{array}$ & phytoplanktivorous, detritivorous & & & intermediate \\
\hline Crangon crangon & carnivorous, macro-benthivorous & Marchand, 1981 & & sediment \\
\hline $\begin{array}{l}\text { Palaemon spp. } \\
\text { Mysids }\end{array}$ & carnivorous, mysid feeder & Marchand, 1981; Sorbe, 1983; Castel et al., 1994; Mouny et al., 1998 & $*$ & intermediate \\
\hline Mesopodopsis slabberi & phytoplanktivorous & Unpublished data & $*$ & phytoplankton \\
\hline Neomysis integer & detritivorous & Castel et al., 1994; Fockedey \& Mees, 1999 & $*$ & detritus \\
\hline Shistomysis spp. & deposit and filter feeder & Unpublished data & $*$ & phytoplankton \\
\hline Gastrosaccus spp. & deposit and filter feeder & Unpublished data & $*$ & phytoplankton \\
\hline
\end{tabular}


Pasquaud, S. etal. Determination of fish trophic levels in an estuarine system

Estuarine Coastal and Shelf Science, $n^{\circ} 86$. p. 237-246. 2010

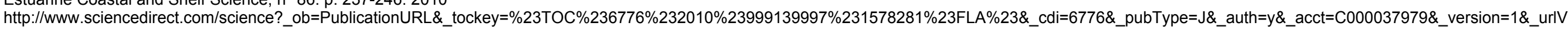

Table 3 (Continued)

\begin{tabular}{|c|c|c|c|c|}
\hline Species & Diet & References & $\begin{array}{l}\text { Gironde } \\
\text { data }(*)\end{array}$ & $\begin{array}{c}\text { Source of } \\
\text { organic matter }\end{array}$ \\
\hline \multicolumn{5}{|l|}{ Copépods } \\
\hline Acartia spp. & phytoplanktivorous & Unpublished data & $*$ & phytoplankton \\
\hline Eurytemora affinis & detritivorous & Castel et al., 1994; Unpublished data & $*$ & detritus \\
\hline Acanthocyclops trajani & 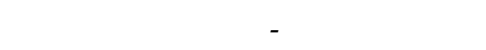 & Unpublished data & $*$ & sediment \\
\hline Euterpina acutifrons & - & Unpublished data & $*$ & intermediate \\
\hline Metazooplankton & planktivorous & Castel et al., 1994 & $*$ & \\
\hline Mysids & planktivorous & Castel et al., 1994 & $*$ & intermediate \\
\hline Mollusc larvae & planktivorous & Castel et al., 1994 & $*$ & intermediate \\
\hline Cypris larvae & planktivorous & Castel et al., 1994 & $*$ & intermediate \\
\hline Nauplii & planktivorous & Castel et al., 1994 & $*$ & intermediate \\
\hline Fish larvae & planktivorous & Castel et al., 1994 & $*$ & intermediate \\
\hline \multicolumn{5}{|l|}{ Fish } \\
\hline Pomatoschistus spp. & planktivorous & present work & $*$ & intermediate \\
\hline Sprattus sprattus & planktivorous & Pasquaud et al., 2008 & $*$ & intermediate \\
\hline Solea solea & hyperbenthophagous, piscivorous & present work & $*$ & sediment \\
\hline Engraulis encrasicolus & planktivorous & Pasquaud et al., 2008 & $*$ & intermediate \\
\hline \multicolumn{5}{|l|}{ Divers } \\
\hline Eggs & - & & & detritus \\
\hline Vegetal debris & - & & & detritus \\
\hline Pollen & - & & & detritus \\
\hline
\end{tabular}

631 
Pasquaud, S. etal. Determination of fish trophic levels in an estuarine system

Estuarine Coastal and Shelf Science, $n^{\circ} 86$. p. 237-246. 2010

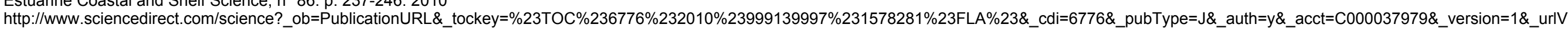

\section{Table 4.}

\begin{tabular}{|c|c|c|c|c|c|c|c|c|c|}
\hline \multirow[b]{2}{*}{ Species } & \multicolumn{4}{|l|}{ SCA } & \multicolumn{2}{|l|}{ Trophic data } & \multicolumn{2}{|c|}{ SIA } & \multirow[b]{2}{*}{$\mathrm{TL}$} \\
\hline & $\mathrm{V} \%_{\mathrm{B}}$ & $\mathrm{V} \%_{\mathrm{P}}$ & & & Trophic chain (source) & $\delta^{15} \mathrm{~N} \pm \mathrm{SD}$ & $\begin{array}{c}\delta^{15} \mathrm{~N}_{\text {base }} \\
\text { estimation }\end{array}$ & $\begin{array}{c}\mathrm{TL}_{\text {base }} \\
\text { estimation }\end{array}$ & \\
\hline & & $\% \mathrm{~V}_{\mathrm{H}}$ & $\% \mathrm{~V}_{\mathrm{D}}$ & $\% \mathrm{~V}_{\mathrm{I}}$ & & & & & \\
\hline C. edule & & & & & benthic & $7.97 \pm 0.39$ & & 2.00 & \\
\hline Acartia spp. & & & & & pelagic (phytoplanktonic) & $6.12 \pm 1.51$ & & 2.00 & \\
\hline E. affinis & & & & & pelagic (detritic) & $7.13 \pm 2.67$ & & 2.00 & \\
\hline Intermediate & & & & & pelagic & $6.63 \pm 0.72$ & & 2.00 & \\
\hline D. labrax ** & 11.72 & 0.00 & 12.89 & 75.39 & mixed & $13.60 \pm 0.12$ & 6.85 & & 3.98 \\
\hline A. anguilla & 11.14 & 0.10 & 11.27 & 77.50 & mixed & $13.26 \pm 0.69$ & 6.83 & & 3.89 \\
\hline D. punctatus & 17.92 & 18.37 & 3.48 & 60.22 & mixed & $12.18 \pm 0.90$ & 6.79 & & 3.58 \\
\hline A. regius $* *$ & 36.36 & 3.93 & 12.69 & 47.02 & mixed & $12.55 \pm 0.68$ & 7.16 & & 3.58 \\
\hline D. labrax* & 37.53 & 17.00 & 0.33 & 45.15 & mixed & $11.91 \pm 0.81$ & 7.05 & & 3.43 \\
\hline P. flesus & 79.96 & 0.00 & 2.27 & 17.77 & benthic & $12.34 \pm 0.95$ & 7.71 & & 3.36 \\
\hline S. solea & 59.41 & 0.00 & 11.59 & 29.00 & benthic & $11.91 \pm 1.01$ & 7.48 & & 3.30 \\
\hline A. regius $*$ & 21.21 & 23.55 & 18.20 & 37.04 & mixed & $10.80 \pm 1.07$ & 6.88 & & 3.15 \\
\hline Pomatoschistus spp. & 3.57 & 0.00 & 26.44 & 70.24 & mixed & $10.70 \pm 0.50$ & 6.83 & & 3.14 \\
\hline L. ramado & 94.68 & 1.73 & 0.00 & 3.58 & benthic & $10.85 \pm 1.43$ & 7.89 & & 2.87 \\
\hline
\end{tabular}

